\title{
A IMPLEMENTAÇÃO DO PNAIC EM TERRITÓRIO VULNERÁVEL NO MUNICÍPIO DE SÃO PAULO
}

\author{
LA IMPLEMENTACIÓN DE PNAIC EN TERRITORIO VULNERABLE EN EL \\ MUNICIPIO DE SÃO PAULO
}

\author{
THE IMPLEMENTATION OF PNAIC IN VULNERABLE TERRITORY IN THE \\ MUNICIPALITY OF SÃO PAULO
}

\author{
Silvana Menegoto Nogueira DI GIUSTO ${ }^{1}$ \\ Vanda Mendes RIBEIRO ${ }^{2}$ \\ Claudia Lemos VÓVIO ${ }^{3}$
}

RESUMO: Este artigo trata da implementação do Programa Pacto Nacional para Alfabetização na Idade Certa (Pnaic) na Rede Municipal de Ensino de São Paulo (RMESP), em território de vulnerabilidade social. A pesquisa empregou entrevistas entre agentes implementadores de nível macro, meso e micro, analisadas a partir de categorias advindas da literatura sobre políticas públicas. Constatou-se resistência ao Pnaic no município estudado devido às prescrições didáticas para o desenvolvimento da consciência fonológica e às situações interpretadas como descompromisso dos agentes de nível macro com o programa. Implementadores do Programa usaram de sua discricionariedade por meio de adequações nas diretrizes para lidar com tais resistências e para incluir coordenadores pedagógicos nas formações. Estratégias específicas para garantia da alfabetização nos contextos de vulnerabilidade social não foram observadas.

PALAVRAS-CHAVE: Pnaic. Políticas educacionais. Implementação de políticas públicas. Alfabetização. Vulnerabilidade social no território.

RESUMEN: Este artículo trata de la implementación del Programa Pacto Nacional de Alfabetización en Edad Adecuada (Pnaic) en la Red Municipal de Educación de São Paulo (RMESP), en un territorio de vulnerabilidad social. La investigación empleó entrevistas entre agentes implementadores a nivel macro, meso y micro, analizadas a partir de categorías derivadas de la literatura sobre políticas públicas. La resistencia al Pnaic se encontró debido a prescripciones didácticas para el desarrollo de la conciencia fonológica y a situaciones interpretadas como desvinculación del programa. Se realizaron ajustes a las directrices para hacer frente a estas resistencias e incluir coordinadores pedagógicos en la formación. No se

\footnotetext{
${ }^{1}$ Universidade Cidade de São Paulo (UNICID), São Paulo - SP - Brasil. Mestrado pelo Programa de PósGraduação em Educação. ORCID: https://orcid.org/0000-0001-9997-9631. E-mail: silgiusto@uol.com.br

${ }^{2}$ Universidade Cidade de São Paulo (UNICID), São Paulo - SP - Brasil. Professora do Programa de PósGraduação em Educação e do Programa de Pós-Graduação Formação de Gestores Educacionais. Membro da Rede de Estudos sobre Implementação de Políticas Públicas Educacionais (REIPPE). Doutorado em Educação (USP). ORCID: https://orcid.org/0000-0002-2275-7122. E-mail: vandaribeiro2@gmail.com

3 Universidade Federal de São Paulo (UNIFESP), Guarulhos - SP - Brasil. Professora Associada do Departamento de Educação e Docente do Programa de Pós-Graduação em Educação. Membro da Rede de Estudos sobre Implementação de Políticas Públicas Educacionais (REIPPE). Doutorado em Linguística Aplicada (UNICAMP). ORCID: https://orcid.org/0000-0002-6141-8203. E-mail: cl.vovio@unifesp.br
}

RIAEE - Revista Ibero-Americana de Estudos em Educação, Araraquara, v. 16, n. 3, p. 2148-2178, jul./set. 2021. e-ISSN: 1982-5587 
observaron estrategias para garantizar la alfabetización en contextos de vulnerabilidad social.

PALABRAS CLAVE: Pnaic. Politicas educativas. Implementación de politicas públicas. Literatura. Vulnerabilidad social en el territorio.

ABSTRACT: This article deals with the implementation of Pnaic in the Municipal Teaching Network of Sao Paulo, specifically in a territory of social vulnerability. The research made use of interviews with implementing agents in macro, medium and micro levels, which were analysed on the basis of categories produced in the literature on public policies. Resistances to Pnaic were raised due to didactic prescriptions as to the development of phonological consciousness, as well as through situations interpreted as uncompromising towards the programme. Adjustments designed to deal with these resistances were put in place in the directives, and pedagogical coordinators were included in the processes of formation. On the other hand, strategies to guaranteeing literacy in contexts of social vulnerability were not observed.

KEYWORDS: Pnaic. Educational policies. Implementation of public policies. Literacy. Social vulnerability in the territory.

\section{Introdução}

Este artigo apresenta resultados de pesquisa ${ }^{4}$ cujo objetivo foi o de estudar a implementação do Programa Pacto Nacional para Alfabetização na Idade Certa (Pnaic) na Rede Municipal de Ensino de São Paulo (RMESP), em um território de vulnerabilidade social. O Pnaic foi uma política instituída pela Portaria 867 de 04 de julho de 2012 (BRASIL, 2012a), implementada a partir do Ministério da Educação (MEC), cuja principal estratégia foi a formação continuada e disseminação de subsídios e materiais didáticos e pedagógicos para professores alfabetizadores, prevendo para sua execução a adesão e parceria de entes federados (governo federal, Distrito Federal, estados e municípios) e Instituições de Ensino Superior (IES) públicas. Contou com a adesão anual de mais de 5 mil municípios, durante sua execução, segundo dados do $\mathrm{MEC}^{5}$.

\footnotetext{
${ }^{4} \mathrm{O}$ texto tem origem em dissertação de mestrado, sob o título "A Implementação do Pnaic na rede ensino do município de São Paulo em territórios vulneráveis", realizada no âmbito de uma pesquisa maior, "Implementação de Políticas Educacionais e Equidade em Contextos de Vulnerabilidade Social", financiada pela Fundação de Amparo à Pesquisa do Estado de São Paulo (FAPESP), processo número 2018/11257-6. Esta pesquisa agregou um conjunto de pesquisadores de várias instituições nacionais e internacionais, vários deles da Rede de Estudos sobre Implementação de Políticas Públicas Educacionais (Reippe), sob coordenação de Vanda Mendes Ribeiro, da Unicid. As opiniões, hipóteses e conclusões ou recomendações expressas neste material são de responsabilidade da(s) autor(as) e não necessariamente refletem a visão da FAPESP.

5 Disponível em: http://portal.mec.gov.br/ultimas-noticias/211-218175739/51531-municipios-interessadosdevem-aderir-a-partir-desta-quarta-12. Acesso em: 15 maio 2020.
} 
Duas amplas revisões para identificar estudos sobre o Programa foram realizadas por Alferes e Mainardes (2019) e Xavier e Bartholo (2019). Alferes e Mainardes (2019) realizaram a análise de 64 trabalhos publicados sobre o Pnaic, entre os anos de 2013 e 2016, e constataram a ênfase em estudos que buscam descrever o Programa e analisar documentos e cadernos de formação e a opinião de formadores e professores sobre suas estratégias em detrimento daqueles que abordam o Programa enquanto política educacional. A esse respeito sinalizam a necessidade de estudos que tematizem a produção da política (em nível macro) e de sua execução (em níveis meso e micro). A revisão produzida por Xavier e Bartholo (2019), com ênfase nos impactos e efeitos do Programa, também aponta para faltas: dos 121 estudos analisados pelos autores, apenas quatro deles “estimaram os possíveis efeitos do Pnaic” e não foi encontrado nenhum estudo sobre sua implementação.

A implementação compreende a consecução de uma política pública, na qual interferem diversos fatores, desde aqueles relativos aos valores, interesses, concepções e formação dos implementadores, passando pelo contexto de execução da política, até aqueles relacionados ao grau de discricionariedade dos agentes na tomada de decisões e ações (LOTTA, 2019). Para Arretche (2001, p. 48), essa etapa caracteriza-se por "um certo grau de incerteza quanto à convergência de ações dos implementadores e, por extensão, da perfeita adequação entre formulação original e implementação efetiva”. Assim, analisar a implementação do Pnaic parece de grande valia, já que se trata de um Programa de abrangência nacional, baseado no compromisso e cooperação entre estados e municípios, em um país federativo e multipartidário, no qual os entes têm autonomia política e o Ministério da Educação tem um papel indutor. Como bem sinaliza Arretche (2001), esse contexto pode gerar comportamentos não cooperativos e competitivos.

Estudos da Sociologia da Educação têm constatado que a vulnerabilidade social no território afeta as escolas quanto a sua organização, funcionamento e disposição de recursos humanos e materiais, com impactos negativos sobre o desempenho dos alunos que habitam essas localidades e frequentam essas escolas, impondo desafios às políticas educacionais (RIBEIRO; VOVIO, 2017). Este estudo pretende contribuir para suprir a lacuna detectada pela revisão de literatura mencionada, focalizando a questão da implementação do Pnaic e a compreensão desse processo em territórios de vulnerabilidade social. 


\section{Pacto Nacional pela Alfabetização na Idade Certa na RMESP}

O Pnaic se inspira no Programa de Aprendizagem na Idade Certa (Paic), implementado pelo Estado do Ceará a partir de 2007, tendo como origem o reconhecimento do fenômeno social do analfabetismo escolar. Na Portaria que o institui, previa-se: garantir que todas as crianças estivessem alfabetizadas até o final do $3^{\circ}$ ano do Ensino Fundamental, reduzir a distorção idade-série na Educação Básica e melhorar o Índice de Desenvolvimento da Educação Básica (Ideb) (BRASIL, 2012). O Pacto correspondia ao atendimento de duas metas do Plano Nacional de Educação: a Meta 05, que define a obrigatoriedade da alfabetização até o final do $3^{\circ}$ ano do Ensino Fundamental, e a Meta 02, que estabelece a universalização do Ensino Fundamental de 9 anos, sustentado pelo compromisso assumido pelos entes federados.

O Programa também se justificava a partir do amplo debate sobre a relação entre a formação docente e a qualidade das oportunidades educacionais e se amparou em pesquisas ${ }^{6} \mathrm{e}$ experiências anteriores, de iniciativa federal, como o Pró-letramento ${ }^{7}$ e a Rede Nacional de Formação Continuada, que reunia as universidades públicas como atores fundamentais, em suas ações de formação em rede, junto aos sistemas públicos de ensino e escolas públicas (XAVIER; BARTHOLO, 2019).

Em sua formulação, as ações se estruturavam a partir de quatro eixos principais: 1) Formação continuada (tanto a formação e constituição de uma rede de formadores locais e orientadores de estudo - OE - como a formação de alfabetizadores das redes públicas de ensino participantes); 2) Materiais didáticos, literatura e tecnologias educacionais (livros didáticos e manuais do professor para o ciclo de alfabetização, obras pedagógicas complementares aos livros didáticos, distribuídos a partir do Programa Nacional do Livro Didático, obras de referência, de literatura e de pesquisa, distribuídas pelo Programa Nacional Biblioteca na Escola; jogos pedagógicos voltados à alfabetização e obras de apoio pedagógico aos professores); 3) Avaliações (mediante a aplicação anual da Provinha Brasil aos estudantes das escolas participantes, no início e final do $2^{\circ}$ ano do Ensino Fundamental e tratamento dos resultados, disponibilizando-os para as redes públicas, e avaliação externa universal do nível de alfabetização ao final do $3^{\circ}$ ano do Ensino Fundamental); 4) Controle da Gestão (mobilização e controle social, responsáveis por monitorar e assegurar a implementação do programa).

\footnotetext{
${ }^{6}$ A esse respeito ver os estudos de Gatti e Nunes (2009).

${ }^{7}$ O Pró-letramento - Mobilização pela Qualidade da Educação, lançado em 2005, define-se como um Programa de Formação Continuada para professores.
} 
O arranjo institucional e hierárquico entre as instâncias federal, estadual e municipal, responsáveis pelo monitoramento e supervisão do processo de implementação do Pacto organizava-se a partir de um Comitê Gestor Nacional, da Coordenação Institucional, da Coordenação Estadual e da Coordenação Municipal, cabendo ao MEC o delineamento da formação docente e de seus conteúdos, a elaboração e distribuição de materiais didáticos e pedagógicos, a concessão de bolsas ${ }^{8}$ aos participantes, distribuição de acervos de literatura, a instituição de avaliação estandardizada. Note-se que o governo federal, por meio do Ministério da Educação, concentrava esforços na formulação, regulação e distribuição de recursos. Já a execução esteve sob a responsabilidade de agentes locais, das IES e das redes públicas de ensino.

Segundo a Resolução CD/FNDE n. 4, de 27 de fevereiro de 2013 (BRASIL, 2013), às IES coube definir o coordenador-geral, o coordenador-adjunto, o supervisor e o formador. Além da formação local, a universidade assumiu uma ação complementar à do MEC, na formulação da política, delimitando as diretrizes e conteúdos e produzindo subsídios para a formação continuada. O Centro de Estudos em Educação e Linguagem (CEEL), da Universidade Federal de Pernambuco (UFPE), encarregou-se da produção dos Cadernos de Formação, num total de 34, e dos jogos de alfabetização. Essa produção tomou por base materiais formativos do Programa que o antecedeu, o Pró-letramento, e os Cadernos foram incrementados com novos conteúdos e abordagens sobre o processo de alfabetização, exemplo disso, foi a inclusão da noção de consciência fonológica ${ }^{9}$ e sua defesa como conjunto de habilidades que favorece o domínio do sistema de escrita alfabética, aspecto que fundamenta também os jogos pedagógicos distribuídos no âmbito do Pnaic. Além do tratamento de objetos de ensino, os Cadernos traziam relatos de sala de aula, prescreviam práticas pedagógicas exitosas e modos de gerir a rotina (LOVATO, 2016; MANZANO, 2015). Para além da Língua Portuguesa e alfabetização, foram incorporadas outras disciplinas, como Matemática. As IES locais também elaboraram textos e indicaram obras complementares. Todos esses materiais eram dirigidos aos $\mathrm{OE}$ e aos professores alfabetizadores.

A adesão do munícipio de São Paulo deu-se em novembro de 2012, ao final da gestão de Gilberto Kassab, contemplando a escolha dos agentes implementadores, tanto no nível da Secretaria Municipal de Educação de São Paulo (SMESP) como no nível da IES formadora. Com o início da gestão de Fernando Haddad, em 2013, houve um conjunto de alterações dos

${ }^{8}$ Cf. Resolução CD/FNDE no 4 de 16 de novembro de 2012 (BRASIL, 2012b).

${ }^{9} \mathrm{Cf}$. Morais (2019).

RIAEE - Revista Ibero-Americana de Estudos em Educação, Araraquara, v. 16, n. 3, p. 2148-2178, jul./set. 2021. e-ISSN: 1982-5587 
agentes implementadores, desde aqueles inscritos para gestão até os participantes dos cursos. A RMESP, uma das maiores redes públicas de ensino da América Latina, organiza-se a partir de 13 Diretorias Regionais de Ensino (DRE), que se ocupavam, à época do estudo, de 538 escolas de Ensino Fundamental, contava com 232.916 alunos matriculados e 10.223 docentes.

Destaca-se ainda que a implementação do Pnaic em São Paulo deu-se de modo concomitante à implementação de uma nova política educacional municipal, o Programa Mais Educação (SÃO PAULO, 2014). O Programa previa a reorganização curricular e administrativa e a ampliação e fortalecimento da RMESP, resultando tanto na organização do ciclo de alfabetização, como previsto pelo Pnaic, quanto na adoção das Diretrizes Curriculares previstas no Pacto pelas escolas municipais ${ }^{10}$, em lugar do currículo estabelecido e dos materiais didáticos anteriormente distribuídos pela RMESP.

Em fevereiro de 2013, iniciaram-se os cursos de formação dos OE no município. O programa foi gerido pelo Comitê Gestor Estadual e duas Instituições de Ensino Superior, a Universidade Federal de São Carlos (UFSCar) e a Universidade Estadual Paulista (Unesp). Foram envolvidos em nível meso, profissionais da educação da SMESP e das DRE e, em nível micro, coordenadores pedagógicos e professores alfabetizadores. Este programa foi finalizado no final do primeiro semestre de 2018.

\section{Implementação de Políticas Educacionais}

Lipsky (2010) e Lotta $(2014 ; 2019)$ defendem que a etapa de implementação deve ser considerada como um processo dinâmico, amplo e abrangente, composta por decisões, embates e interações entre diversos agentes. Lotta (2012), especialmente, considera que os objetivos nem sempre são alcançados devido a variados fatores, entre os enumerados pela autora, interessa-nos: a possibilidade de diferentes interpretações e ações discricionárias, o envolvimento de uma multiplicidade de atores e organismos na implementação, a comunicação e a interação entre atores e instâncias, os interesses e valores dos agentes implementadores e organismos e as motivações para implementação.

A centralidade dos agentes, na implementação, justifica-se, segundo Lipsky (2010), porque eles traduzem as diretrizes junto ao público-alvo, sendo mediadores entre o Estado e o cidadão, fornecendo benefícios ou sanções. Lipsky (2010) identificou que os agentes implementadores fazem uso da discricionariedade, uma autonomia relativa que pode afetar a

${ }^{10}$ Ver Portaria n ${ }^{\circ} 5930 / 13$ de 14 de outubro de 2013; Portaria ${ }^{\circ}{ }^{\circ} 6.571$ de 25 de novembro de 2014 e documento Programa Mais Educação São Paulo: subsídios para a implantação (SÃO PAULO, 2014). 
distribuição de recursos. São responsáveis por determinar a natureza, a quantidade e a qualidade dos serviços, e o fazem de acordo com concepções subjetivas oriundas de suas trajetórias, valores, formação, treinamentos e experiência profissional, ademais, sofrem influências do contexto político, institucional e econômico em que operam (LIPSKY, 2010).

Lipsky (2010) e Lotta (2014; 2019) apontam que podem existir diversos níveis de discricionariedade, dependendo de fatores pessoais e institucionais. Quanto aos agentes implementadores, Arretche (2001) indica três questões a serem consideradas: se conhecem o programa, a fim de não elegerem outras referências para a implementação; se aceitam os objetivos e as regras do programa, pois caso discordem podem eleger suas próprias; se as condições institucionais são adequadas, evitando assim adaptações que muitas vezes se distanciam do desenho previsto.

Segundo Hill (2003), processos formativos colaboram para promover, na implementação, conhecimentos, habilidades e razões para fazer política, para estimular mudanças e melhorar os resultados finais e evitar o peso da subjetividade ou de experiências prévias na tomada de decisões, em processos de negociação ou desajustes de condutas.

Tratando especificamente de programas educacionais, que envolvem variados atores e instâncias institucionais, Torres et al. (2010) destacam fatores que interferem na atuação dos professores (tais como salário, motivação, modelos e imagens a respeito dos alunos, especialmente mais pobres, local de trabalho) que podem gerar a diferenciação das oportunidades educacionais entre beneficiários distintos da política, criando ou reforçando processos de discriminação. Esses autores tratam também da descontinuidade das diretrizes e ações que promovem instabilidade na escola, especialmente das diferenças de procedimentos e condutas quando há mudança de governo, com implementações efetuadas de forma rápida, incompleta e sem processos de transição.

Torres et al. (2010) discutem ainda os desafios da execução de políticas públicas educacionais universais em espaços urbanos heterogêneos, tendo em vista as condicionalidades que intervêm nesse processo, por exemplo, as características das instituições; os processos formativos e de comunicação; as características das estratégias adotadas; a legitimidade das decisões feitas pela autoridade governamental; as interações entre as instituições e agentes; os valores, preferências, crenças e grau de autonomia dos agentes; o grau de discricionariedade; os conflitos e interesses envolvidos nos processos de implementação; as trajetórias profissionais e pessoais dos agentes; as características das relações hierárquicas nas instituições; a motivação e capacitação dos agentes; os contextos 
cultural, político, histórico das instituições e agentes; a linguagem e construção de significados junto aos agentes; as condições de trabalho dos agentes implementadores.

\section{Vulnerabilidade Social no Território e os processos educativos}

Para Kaztman (2000), territórios vulneráveis são caracterizados pelo acesso restrito a condições de melhoria do bem-estar, com frágeis laços dos indivíduos com o mercado de trabalho, isolamento sociocultural e político, homogeneidade social, baixa escolaridade e baixo acesso a serviços públicos e privados. Esse autor afirma que a vulnerabilidade social não pode ser captada somente pela dimensão da renda familiar, sendo mais abrangente que o fenômeno da pobreza.

A literatura sobre vulnerabilidade social no território tem considerado a escolarização como um dos recursos que mais contribui para a obtenção de bens e serviços, e que mais contribui com as famílias que ali residem, inclusive no que se refere à mobilidade social. Ribeiro e Koslinski (2010), em estudo sobre o efeito vizinhança na escola, afirmam que as características do local de residência têm impacto sobre as condições de vida, mobilidade social e destino escolar de seus moradores, interferindo nas oportunidades educacionais.

Érnica e Batista (2012), Koslinski, Alves e Lange (2013), Ribeiro e Koslinski (2010) identificaram que alunos em escolas de regiões mais vulneráveis tendem a apresentar pior desempenho escolar. Christovão e Santos (2010) e Marcucci (2015) detectaram que estigmas negativos e baixa expectativa com relação aos estudantes nessas condições levam a comportamentos como baixo investimento pedagógico, simplificação de conteúdos e redução do tempo dedicado à aprendizagem.

Pereira-Silva (2016) denota, após análise conceitual e de resultados de pesquisas realizadas em São Paulo e Rio de Janeiro, que a vulnerabilidade social no território desafia sobremaneira a distribuição justa do conhecimento na escola ${ }^{11}$, havendo sobreposição de fatores internos e externos que, sozinhos, já têm potencial de incidir negativamente sobre a desigualdade escolar. Atuando em conjunto, nesses territórios, não permitem o pleno desenvolvimento das funções da instituição enquanto promotora de saberes.

11 Ribeiro (2014) lembra que competências e aprendizagens não adquiridas na escola de forma equitativa comprometem a trajetória escolar dos alunos e, por consequência, a aquisição de outros bens sociais valorizados, como postos de trabalho melhor remunerados, reproduzindo processos de desigualdades. 


\section{Procedimentos metodológicos}

Trata-se de um estudo qualitativo, cujo principal instrumento foi a aplicação de entrevistas semiestruturadas. A aplicação ocorreu no município de São Paulo, entre setembro de 2016 e junho de 2017, após quatro anos da implementação do Pnaic no município. Participaram 10 agentes implementadores em níveis macro, meso e micro, pertencentes à Secretaria Municipal de Ensino de São Paulo, a uma das Diretorias de Regionais de Educação do município e duas escolas do território vulnerável da qual faz parte a referida DRE. A DRE de São Miguel Paulista, o lócus privilegiado desse estudo, está localizada no extremo leste, abriga 51 escolas municipais de Ensino Fundamental e 203 escolas de Educação Infantil, atende cerca de 9 mil alunos, distribuídos por seus sete distritos: Itaim Paulista, Jardim Helena, Lajeado, São Miguel, Vila Curuçá, Vila Jacuí e Vila Maria. Sua escolha deveu-se à consideração de que se trata de uma localidade de vulnerabilidade social, com o Índice Paulista de Vulnerabilidade Social (IPVS) de 4,2 (SEADE, 2010), atendendo aos critérios desse estudo, e tendo participado de outras investigações que tratam do efeito território sobre as oportunidades educacionais (ALVES et al., 2015; BATISTA; CARVALHO-SILVA, 2013; ERNICA; BATISTA, 2012).

As entrevistas prestaram-se para captar a percepção de agentes implementadores no município de São Paulo sobre o Pnaic. O roteiro explorava os seguintes tópicos: o processo de implementação do Pnaic; as atribuições de distintos agentes nesses processos; os pontos positivos e negativos da formação e das propostas pedagógicas; as facilidades e dificuldades encontradas durante a implementação; e as possíveis adaptações realizadas, considerando também as necessidades impostas pela vulnerabilidade social do território.

O Quadro 1 apresenta um breve perfil dos 10 agentes entrevistados, representantes da SMESP, da DRE de São Miguel Paulista e de duas escolas municipais dessa diretoria. Cada um deles teve oportunidade de elaborar suas respostas e depoimentos de forma espontânea e livre.

Quadro 1 - Perfil dos entrevistados

\begin{tabular}{|l|l|l|l|l|l|}
\hline $\begin{array}{c}\text { Nome } \\
\mathbf{1 2}\end{array}$ & \multicolumn{1}{|c|}{$\begin{array}{c}\text { Vínculo } \\
\text { Empregatício }\end{array}$} & $\begin{array}{c}\text { Tempo } \\
\text { na } \\
\text { função }\end{array}$ & $\begin{array}{c}\text { Função } \\
\text { no Pnaic }\end{array}$ & $\begin{array}{c}\text { Nível de } \\
\text { implementaç } \\
\text { ão }\end{array}$ & $\begin{array}{c}\text { Local de } \\
\text { Trabalho }\end{array}$ \\
\hline $\begin{array}{l}\text { Auror } \\
\text { a }\end{array}$ & Secretária Adjunta de Educação. & 6 meses & $\begin{array}{l}\text { Coord. Municipal e } \\
\text { Estadual }\end{array}$ & Macro & SMESP \\
\hline $\begin{array}{l}\text { Migue } \\
1\end{array}$ & Diretor Regional & 10 anos & & Meso & $\begin{array}{l}\text { DRE/SMES } \\
\text { P }\end{array}$ \\
\hline
\end{tabular}

${ }^{12}$ A fim de preservar a identidade dos entrevistados os nomes são fictícios. 


\begin{tabular}{|l|l|l|l|l|l|}
\hline Maria & Diretora da Divisão. Pedagógica & 3 anos & Coord. Regional & Meso & $\begin{array}{l}\text { DRE/ } \\
\text { SMESP }\end{array}$ \\
\hline Ana & Auxiliar Técnico de Educação (ATE) & 4 anos & OE - Formadora & Meso & $\begin{array}{l}\text { DRE/ } \\
\text { SMESP }\end{array}$ \\
\hline Karen & Coordenadora Pedagógica & 8 anos & OE - Formadora & Micro & Escola A \\
\hline Laura & Coordenadora Pedagógica & 6 anos & OE - Formadora & Micro & Escola B \\
\hline Bruna & $\begin{array}{l}\text { Professora de Educação Infantil e Ensino } \\
\text { Fundamental I }\end{array}$ & 12 anos & $\begin{array}{l}\text { Professora } \\
\text { Alfabetizadora }\end{array}$ & Micro & Escola A \\
\hline Mirela & $\begin{array}{l}\text { Professora de Educação Infantil e Ensino } \\
\text { Fundamental I }\end{array}$ & 7 anos & $\begin{array}{l}\text { Professora } \\
\text { Alfabetizadora }\end{array}$ & Micro & Escola A \\
\hline Renata & $\begin{array}{l}\text { Professora de Educação Infantil e Ensino } \\
\text { Fundamental I }\end{array}$ & 14 anos & $\begin{array}{l}\text { Professora } \\
\text { Alfabetizadora }\end{array}$ & Micro & Escola B \\
\hline Neusa & $\begin{array}{l}\text { Professora de Educação Infantil e Ensino } \\
\text { Fundamental I }\end{array}$ & 17 anos & $\begin{array}{l}\text { Professora } \\
\text { Alfabetizadora }\end{array}$ & Micro & Escola B \\
\hline
\end{tabular}

Fonte: Elaborado pelos autores

As duas escolas participantes foram identificadas como A e B. São escolas diferentes estruturalmente (uma maior e mais antiga e outra menor e mais recente), próximas fisicamente e similares quanto ao público atendido. Possuem resultados educacionais semelhantes e abaixo da média municipal. Quanto ao índice de complexidade de gestão (ICG), segundo o Instituto Nacional de Estudos e Pesquisas Educacionais Anísio Teixeira (INEP, 2018), a escola A é classificada no nível 3, enquanto a B está no nível 5, numa escala até 6. As proficiências médias em Língua Portuguesa e Matemática, em 2015, nos anos iniciais do Ensino Fundamental, foram de 198,04 e 215,13 na escola A e de 202,3 e 216,2 na escola B, e estavam abaixo da média das escolas municipais de São Paulo, à época (QEDu, 2018). O Ideb, em 2015, de ambas foi de 5,6, abaixo da meta estabelecida de 5,8 (INEP, 2018). As taxas de reprovação para os anos iniciais do Ensino Fundamental foram, em 2016, de $0,2 \%$ na escola A e de $0,7 \%$ na escola B (QEdu, 2018).

As entrevistas foram gravadas em áudio e, posteriormente, transcritas. A primeira organização dos dados deu-se a partir da leitura exaustiva de cada uma delas, ordenando as mensagens a partir de categorias pré-definidas. Tais categorias tomaram por base o quadro teórico sobre implementação de políticas públicas e educacionais mobilizado neste estudo, focalizando os seguintes fatores intervenientes nesse processo, a saber: 1) Adesão dos agentes implementadores aos objetivos e metodologias do programa. 2) Capacitação e treinamentos adequados e coerentes, com clareza de objetivos e regras do programa. 3) Discricionariedade dos agentes implementadores. 4) Processos de interação e contexto institucional. 5) Descontinuidade dos programas e diretrizes. Além dessas categorias, elegeu-se outra, com base nos estudos sobre a relação entre as oportunidades educacionais e a vulnerabilidade social no território: 6) Contexto de vulnerabilidade social e outros fatores sociais que dificultam as condições favoráveis para a aprendizagem. Decorrente da imersão nos dados, 
elaborou-se um quadro comparativo, com as repostas e o tratamento dado a cada uma dessas categorias, a partir das narrativas dos agentes implementadores.

\section{Análise}

\section{Adesão dos agentes implementadores aos objetivos e metodologias de operação dos programas}

No ano de 2013, dentre os 490 professores alfabetizadores atuantes na época na DRE de São Miguel, apenas 53\% concluíram a formação continuada em Língua Portuguesa (LP) oferecida pelo Pnaic. Em 2014, com uma adesão menor, cerca de 33\% dos docentes que iniciaram a formação em Matemática a concluíram. Os depoimentos dos gestores da DRE indicam que muitos abandonaram a formação ou a própria implementação do programa por motivos diversos, dentre eles, licenças médicas ou aposentadoria.

Os dados da pesquisa sugerem que o fator que mais contribuiu para esse fenômeno foram os conhecimentos, experiências prévias, valores e crenças dos profissionais da DRE e das escolas que os levaram a uma determinada interpretação das propostas pedagógicas do Pnaic. No Programa e Cadernos de Formação, defendia-se o desenvolvimento da consciência fonológica como meio para favorecer o processo de apropriação do sistema de escrita alfabética dos alunos. Prescrevia-se o desenvolvimento de práticas pedagógicas que favorecessem a "consciência fonológica", o que foi considerado inadequado por profissionais habituados, desde muito, a uma certa abordagem construtivista para alfabetização. Também gerou resistências o entendimento, por parte dos cursistas, de que o Pnaic propunha a alfabetização a partir de métodos tradicionais, de marcha sintética, que previam o fonema ou a sílaba como unidade de ensino. Maria, Diretora da Divisão Pedagógica e Coordenadora Regional do Pnaic, afirma que havia essa "distorção na compreensão". A professora Bruna (Escola A) explica: "Quando o Pnaic chegou a princípio rolou um estranhamento porque era uma outra proposta.". E continua: "Tanto que muitas colegas que iniciaram a formação desistiram. A gente teve muitos casos assim [...]".

Bruna (Escola A) explicita também a resistência aos jogos de alfabetização distribuídos pelo Pnaic, que enfatizavam conteúdos voltados à consciência fonológica, tais como a análise oral e por escrito de palavras, focalizando unidades como a sílaba, as rimas, a 
aliteração, por exemplo. Seu depoimento dá a entender que baseava-se em referências anteriores, advindas de outras formações, tais como o Programa Ler e escrever ${ }^{13}$ :

Eu não abandonei algumas práticas, porque eu achei que é interessante e ainda hoje continuo com essas práticas nessa visão mais construtivista, com orientação mais do programa que a gente trabalhava, Ler e Escrever. Achei que ele (Pnaic) estava apresentando uma proposta diferente, que de certa forma ampliou e abriu mais o leque. Cheguei a usar algumas vezes as atividades (referindo-se aos jogos), Eu não entendi que eu precisava jogar tudo fora [das práticas] anteriores e implantar a orientação do Pnaic e pronto e acabou. Para mim não. Eu achei que eu poderia mesclar. (Professora Bruna).

Os depoimentos dos agentes evidenciam ainda que houve treinamentos sendo realizados de forma simplificada e acelerada, o que promoveu insatisfação dos cursistas e a não adesão em anos subsequentes.

[...] porque a (formação em) Matemática não atendeu as expectativas deles (professores). Primeiro porque a proposta era de 20 encontros, reduziu para 10. Foi uma confusão em termos de organização. E isso desestimula muito o professor porque ele percebe que a formação foi a toque de caixa. [...] para o outro ano é lógico que houve uma queda [...], muitos desistiram. (Coordenadora Pedagógica Laura).

Além desses problemas, segundo duas $\mathrm{OE}$, havia problemas na organização dos cursos de formação. Laura, Coordenadora pedagógica (Escola B), aponta para as dificuldades na organização dos cursos: “foi uma confusão em termos de organização, entendeu?". Ana, ATE da DRE, considera que as condições de participação variaram, o que gerou problemas na adesão dos professores aos cursos (num momento, foram realizadas aos sábados e, em outro, no horário de serviço dos professores). Em suas palavras, "No horário de serviço, nós tínhamos toda uma logística para não atrapalhar. E nós privilegiamos que todos participassem nessa formação. Mas [para o Sábado] nem sempre as pessoas têm disponibilidade”. Ou seja, a bolsa oferecida aos cursistas não foi incentivo suficiente para impedir a baixa adesão, quando a formação se deu fora do horário de trabalho.

Corroborando Arretche (2001), os dados acima indicam que o Programa teve, no quesito adesão, problemas na implementação. Para essa autora, o sucesso de um programa depende primeiramente de obter a adesão dos agentes implementadores aos objetivos e à metodologia de operação. Em caso de resistência parcial ou total aos objetivos e métodos, o agente poderá criar

${ }^{13}$ O Programa Ler e Escrever teve início em 2007 na rede estadual de ensino, é um conjunto de ações articuladas que inclui formação de professores, coordenadores pedagógicos e técnicos, acompanhamento das aprendizagens dos alunos, elaboração e distribuição de materiais pedagógicos e outros subsídios (OBSERVATÓRIO DO PNE, 2017). 
suas próprias interpretações das regras ou mesmo negar-se a participar do programa ou de implementá-lo.

A pesquisa denota que foram fundamentalmente três os maiores motivos das desistências ou falta de adesão nas escolas: 1) crenças relativas aos métodos de alfabetização; 2) simplificação dos conteúdos formativos e desorganização na organização dos cursos, sobretudo de Matemática, gerando a compreensão entre os agentes das escolas de que o Programa não era algo entendido pelos implementadores em nível macro como diretriz que teria vindo para ficar; 3) a oferta de formações fora do horário de serviço. Não houve relatos que permitam afirmar resistências aos objetivos do Pnaic.

\section{Capacitação e treinamentos adequados e coerentes com clareza de objetivos e regras do programa}

Segundo Hill (2003) e Torres et al. (2010), a formação e o treinamento dos agentes são primordiais para alinhamento de conceitos, habilidades e práticas, além de buscar diminuir as adaptações e distorções promovidas pelos implementadores diante de decisões vagas e conflitantes. Em diversas entrevistas, as experiências nos cursos de formação do Pnaic, tanto por parte dos gestores, como dos OE ou mesmo dos professores foram tematizadas, o que era esperado, considerando-se que a formação continuada é um dos principais pilares do programa, e, na RMESP, foi realizada de forma muito intensa, com envolvimento de diversos profissionais em suas diferentes etapas de planejamento, organização e execução. Entretanto, a implementação do Pnaic na capital paulista, apesar de mobilizar diversos profissionais e recursos, e ter sido considerada muito proveitosa pelos participantes e organizadores, apresentou, de acordo com a pesquisa, algumas questões em seus treinamentos que geraram rejeições e adaptações do programa e seus materiais.

Uma dessas questões diz respeito à prescrição de conteúdos e práticas pedagógicas voltadas ao desenvolvimento da consciência fonológica, que, sendo mal interpretada, foi confundida com a proposição de métodos tradicionais de alfabetização, como o método fônico ou silábico, como nos explica a gestora Maria, Diretora da Divisão Pedagógica e Coordenadora Regional do Paic, a esse respeito:

[...] o material [proposto pelo Pnaic] trouxe algumas questões que eram novas e tinham distorções na compreensão, por exemplo, a consciência fonológica. Emilia Ferreiro já falava de consciência fonológica lá nos seus livros logo no começo, só que muitos educadores achavam que era silabação. E não era. (Gestora Maria).

RIAEE - Revista Ibero-Americana de Estudos em Educação, Araraquara, v. 16, n. 3, p. 2148-2178, jul./set. 2021. e-ISSN: 1982-5587 
Houve, então, controvérsias, dúvidas e rejeições, devido a concepções arraigadas na rede construídas em outros processos formativos, com forte hegemonia de preceitos construtivistas, disseminados pelo Profa (Programa de Formação de Professores Alfabetizadores) ${ }^{14}$ e pelo Ler e Escrever, implementados anteriormente no município. A coordenadora pedagógica e $\mathrm{OE}$ do Pnaic, Karen (Escola A), refere-se a esse momento controverso:

[...] A rede municipal não vinha trabalhando com essa linha conceitual [de base fonológica], vinha trabalhando com o olhar mais pra questão socioconstrutivista. Quando o programa chega aqui em São Paulo ele dá meio que um choque nos próprios formadores [orientadores de estudos] que vinham recebendo uma formação nessa linha e passam a ter contato com essa outra linha [...]. (Coordenadora Pedagógica Karen).

Outra crítica recorrente quanto à formação foi a descontinuidade por parte dos participantes. Algumas professoras entrevistadas relatam participação em apenas algumas edições dos treinamentos. Essa ausência é justificada pelo fato de não estarem lecionando na alfabetização na época de realização dos cursos e, portanto, não puderam participar das formações. Essa situação foi relatada pelas professoras mais jovens e ratificada por profissionais da DRE. No ano da formação, não possuíam sala fixa e não lecionavam exclusivamente na alfabetização, o que era uma exigência do Programa. No ano seguinte, se entrassem em sala de alfabetização, não receberiam a formação. A professora Bruna (Escola A) confirma esse fato, quando não pode participar da formação de Matemática, em 2014, por não estar lecionando na alfabetização naquele momento, e acabou perdendo esse conteúdo: "No segundo ano foi de Matemática, não participei porque eu estava com outra turma, não estava no ciclo de alfabetização e por isso não poderia participar."

Segundo depoimentos, houve também o caso das formações realizadas em 2015, abordando outras áreas do conhecimento (História, Geografia e Artes) e, em 2016, sobre avaliação, efetivadas em poucos encontros, com tempo restrito para discussão dos assuntos e sem material de apoio didático. A coordenadora pedagógica e OE Laura (Escola B) narra como foi sua experiência como formadora, considerando esses aspectos:

A edição do Pnaic das áreas do conhecimento foi 'Vapt-vupt'. Foi muito rápida mesmo, então não aprofundou nada, foi muito superficial, o que foi muito ruim, porque os professores estavam numa ansiedade para discutir

${ }^{14}$ O Profa foi lançado em dezembro de 2000 pela Secretaria de Educação Fundamental do Ministério da Educação (SEF/MEC) com o objetivo de oferecer novas técnicas de alfabetização aos professores, com base nas pesquisas de Emília Ferreiro e Ana Teberosky, na obra "Psicogênese da Língua Escrita" (MENEZES; SANTOS, 2001). 
História, Geografia, Ciências, Artes, a própria Educação Física. [...]. E faltou material, esse material não chegou até hoje. [...] Era um curso que era para ser em 20 encontros, aí reduziu para 10, depois reduziu para 5. E as outras horas ficaram tudo em EAD (ensino à distância). (Coordenadora Pedagógica Laura).

Outra questão problemática refere-se à distribuição dos materiais didáticos e de apoio pedagógico, tanto para uso nos cursos (Cadernos de Formação), como em sala de aula (jogos de alfabetização e livros de literatura). Laura conta ainda que a distribuição dos materiais de apoio ocorreu de forma dessincronizada com os cursos, comprometendo o acompanhamento por parte dos participantes: “[...] uma coisa é você ir para uma formação no seu primeiro dia, já recebe o material e aí você tem a formação. [...]. Agora no Pnaic, nas 3 edições que trabalhei, o material chegou ou no fim ou já tinha acabado o curso".

Além disso, essa mesma coordenadora também critica o fato deste material de apoio vir em formato digital, seja na distribuição de CD ou para download pela internet:

Não é todo professor que consegue acessar essa questão do uso da tecnologia. Professor ainda está muito apegado a essa coisa do livro, do material fisico. O que tá certo! Porque o cara tá aqui no dia a dia, ele vai pra sala de aula, se ele tem um material impresso ele carrega com ele, risca, grifa, consulta. As escolas não têm equipamento ainda com uma internet mega power, que a todo tempo dá pra você consultar ou imprimir. [...]. Então isso é uma das coisas que eu acho que foi muito ruim. (Coordenadora Pedagógica Laura).

Com base na percepção dos agentes implementadores, houve diversos obstáculos enfrentados na formação dos agentes: a organização dos treinamentos efetivada com variações nos modos de organizar os cursos; a controversa em relação à prescrição de conteúdos voltados à consciência fonológica vis-à-vis aos conhecimentos e experiências prévias dos professores sobre a alfabetização; a precária distribuição de materiais de formação e de apoio, efetivada de forma desarticulada; a impossibilidade de participação de jovens professores, que, à época, não lecionavam na alfabetização; e a descontinuidade dos cursos, realizados de forma simplificada e reduzida. Tendo em vista que a formação continuada era uma estratégia basilar do Pnaic, os problemas apontados, abrem um leque de riscos para a política, seja por problemas de interpretações de seus objetivos e diretrizes, seja pela tomada de decisões vagas, conflituosas ou desajustes de condutas, como asseverado por Hill (2003). O processo de interpretação de suas diretrizes, objetivos e até prescrições ficou circunscrito aos conhecimentos e experiência prévias dos agentes, especialmente, dos professores, o que pode gerar algo bem diferente do que está estabelecido e previsto como meta. Hill (2003) e Torres et al. (2010) asseveram ainda a importância da capacitação no marco da implementação,

RIAEE - Revista Ibero-Americana de Estudos em Educação, Araraquara, v. 16, n. 3, p. 2148-2178, jul./set. 2021. e-ISSN: 1982-5587 
como meio de fornecer aos implementadores mais recursos intelectuais na forma de conhecimentos, habilidades e razões para fazer a política, o que, no caso em tela, ficou obscurecido por problemas de ordem de valores, funcional e organizativa.

\section{Discricionariedade por parte dos agentes implementadores}

De acordo com Lipsky (2010) e Lotta (2014), agentes implementadores elaboram julgamento das diferentes situações que se apresentam e têm certa liberdade de escolher qual conduta irão adotar (discricionariedade). Esse julgamento e escolha são pautados por sua interpretação pessoal das regras e por seus próprios referenciais. A pesquisa denotou o uso da discricionariedade por parte dos $\mathrm{OE}$ que julgaram que era necessário aproximar o material trazido pelo Pnaic à realidade da rede municipal de São Paulo. Avaliaram que o público-alvo da formação não poderia receber as orientações tais como descritas, devido, sobretudo, aos conflitos entre conhecimentos e experiências prévias dos professores, advindas de processos formativos anteriores versus os conteúdos e práticas pedagógicas prescritas pelo Pnaic, especialmente o estabelecimento de conteúdos voltados à consciência fonológica na alfabetização, interpretado como a retomada de métodos tradicionais de alfabetização, fônico e silábico. Conforme descreve a coordenadora pedagógica Laura (Escola B):

Os grupos de formadores nas regiões foram estabelecendo outras diretrizes para a sua região. A gente recebia a formação e pouco dela conseguíamos utilizar, porque a gente achava que não conversava com os nossos professores. [...]. Então tínhamos que construir um outro percurso. (Coordenadora Pedagógica Laura).

Uma adaptação considerada bem-sucedida, identificada no local investigado, refere-se à inclusão dos coordenadores pedagógicos nos cursos de formação do Pnaic. São Paulo é um município que apresenta esse tipo de profissional da educação em sua rede de ensino, entretanto, o desenho do programa não estabelecia essa capacitação, inclusive não fornecia bolsa ou pontuação a quem voluntariamente participasse da formação. A gestora Maria (DRE), Coordenadora Regional do Pnaic, relata:

[...] fizemos um grupo de estudo da DRE e nas reuniões a gente falava tudo o que estava acontecendo no Pnaic de forma geral, para eles também [os coordenadores] acompanharem. E até porque, os professores levavam tarefas e atividades. (Gestora Maria).

Depreende-se neste caso, como destaca Lipsky (2010), a interferência dos agentes implementadores, fazendo uso de sua discricionariedade, mas no sentido de propor ações que 
buscam otimizar os resultados das políticas: o envolvimento dos coordenadores nas formações, situação não prevista no desenho do Pnaic.

Notificou-se também adaptações efetivadas pelas instituições escolares e seus docentes, com a finalidade de adequações de conteúdos e práticas junto aos estudantes. Nesse caso, as professoras julgaram que havia conteúdos não condizentes com as necessidades dos alunos. Como expressa a professora Bruna (Escola A):

Eu tento seguir o currículo, mas eventualmente a gente precisa fazer adaptações, em função de quando é uma criança que tem uma ou outra especificação, mais dificuldade, a gente tem que adaptar e é necessário porque a gente precisa atingir essa criança, nem que a gente pare [...] e que aquela atividade que a gente programou para desenvolver três, a gente desenvolva só uma. (Professora Bruna).

A rejeição à proposta de trabalho com consciência fonológica trouxe também a resistência aos jogos didáticos com essa abordagem, levando a adaptações, conforme cita a coordenadora Laura (Escola B): “[...] no começo do ano eu pergunto quais professores querem utilizar [jogos e materiais didáticos fornecidos pelo Pnaic], porque muitos professores não concordam com aquele material, não gostam, então eu deixo livre".

A coordenadora pedagógica Karen (Escola A) também menciona sobre a rejeição:

[...] eu achei muito interessante, jogos dentro da concepção fônica. Eram jogos diferentes, coisas que a gente não tinha acesso. Agora, eu não conheço uma escola ou uma prática que tenha desenvolvido esse trabalho e que abraçou a todos literalmente item por item ali presentes, eu não conheço. Até porque, como eu te disse, no domínio da base alfabética que eu enxergo esse grande distanciamento [entre o Pnaic e as ações já utilizadas. (Coordenadora Pedagógica Karen).

A pesquisa sugere que a própria instituição escolar estimulou e deu ampla liberdade aos profissionais para realizarem adaptações. Essa pesquisa não se propôs a avaliar as características dessas adaptações, seus alcances ou mesmo o seu impacto sobre a implementação do Pnaic nas escolas. Portanto, não se pode afirmar se foram realizadas com o único objetivo de atender as necessidades de aprendizagem dos estudantes ou mesmo que tenham alcançado os resultados efetivamente esperados. Pode-se, no entanto, afirmar que estão amplamente relacionadas aos valores e interpretações dos profissionais, corroborando assim a literatura sobre implementação de política públicas: para Lipsky (2010), a discricionariedade dos agentes implementadores está em determinar a natureza, a quantidade e a qualidade dos benefícios, podendo haver distintas distribuições desses benefícios, com sanções ou com maior ou menor envolvimento e intensidade, dependendo da análise que 
fazem sobre quem é ou não merecedor do benefício. Esse seria um importante ponto de pesquisa para o futuro: os professores adaptaram conteúdos do Pnaic para os alunos para favorecer a aprendizagem por que consideravam que facilitariam a aprendizagem dos conteúdos ou o fizeram porque acreditavam que eles não poderiam aprendê-los? Essa pergunta se reveste de interesse uma vez que Alves et al. (2015) indica a existência de estigmas sobre alunos de favelas e localidades consideradas "nativamente" mais vulneráveis.

\section{Processos de interação e contexto institucional}

As relações interpessoais e as condições de trabalho interferem no desempenho profissional dos agentes implementadores e são passíveis de interferir nos resultados das políticas públicas, desta forma, é importante conhecer as relações e os aspectos institucionais que influenciam suas ações (ARRECTHE, 2001; LOTTA, 2014).

Como menciona a coordenadora pedagógica Karen (Escola A):

[...] é um facilitador quando você tem a equipe afinada conceitualmente. Porque o diretor... ele é o que toca o barco, a chefia da unidade, mas tem que ter um projeto político pedagógico mais alinhado e isso passa pela direção e a equipe mais ou menos afinada. (Coordenadora Pedagógica Karen).

As entrevistas permitem inferir que as trocas de experiências entre colegas de profissão, ocorridas durante os cursos de formação, foram avaliadas pelos educadores como enriquecedoras para o aprimoramento de conhecimentos. A professora Neusa (Escola B) comenta: “[...] o que o Pnaic proporcionou foi exatamente essa questão da troca de experiências, a gente conversava bastante. E você aprende com a experiência do outro [...]”" Pesquisando em duas outras escolas, nesse mesmo território, Breches (2015) anunciou haver entre os professores, um tipo de troca de pares informal que, considerando as exigências de formação explicitadas pela literatura (TARDIF, 2014; IMBERNÓN, 2009), não seria capaz de dar todas as respostas às questões dos professores frente às necessidades da aprendizagem dos alunos. Quando se analisa a avaliação positiva dos professores participantes, sobre a incidência da formação na troca entre pares, pode-se inferir que a formação do Pnaic pode ter contribuído para aprendizagens profissionais, fornecendo meios formativos mais estruturados e menos informais para o âmbito escolar.

Entretanto, outras falas, possibilitam questionar que o Pnaic tenha conseguido esse resultado. Considerando o ambiente institucional, muitos relatos de profissionais das escolas são coincidentes em apontar, como fatores que dificultaram a sua atuação, o número 
excessivo de alunos por sala de aula, a falta de suporte das famílias nos processos educacionais e a presença de estudantes com deficiências nas salas regulares. A professora Renata (Escola B) afirma: “[...] aí entra a ausência de pais (como ponto que dificulta) [...]. Crianças com deficiência na sala também, e a gente não tá tendo apoio. Eu tenho aluno especial e dá trabalho porque não tenho ninguém pra me ajudar [...]”. A professora Bruna (Escola A) diz: "Eu acho que se houvesse um número um pouco reduzido (de alunos em sala de aula), a gente teria mais tempo para olhar mesmo cada aluno na sua especificidade".

Esses relatos dos professores induzem a inferências distintas das anteriores: que as interações institucionais nas escolas estudadas não foram suficientes para oferecer o apoio que os professores necessitaram para dar respostas efetivas no que diz respeito à sua capacidade de ensinar a todos, foco da política educacional. Os relatos denotam que se sentiam sozinhos. E mencionaram questões externas à escola para justificar as dificuldades encontradas, caso da falta de apoio dos familiares. A fala da professora Bruna, quando afirma que não consegue olhar para cada aluno, para ver sua necessidade específica de aprendizagem, contradiz diretrizes do Pnaic, cujas formações visam contribuir para que o professor consiga alfabetizar todos os alunos na idade certa. Pode-se inferir, portanto, que o Pnaic, nas escolas estudadas, apesar da boa avaliação dos professores sobre a troca de experiências que permitiu, teve dificuldade de gerar um ambiente institucional escolar com interações capazes de estabelecer estratégias para a aprendizagem de todos. Evidentemente novas pesquisas são necessárias para verificar a amplitude deste fenômeno. Sendo ele amplo, o Programa não teria, por exemplo, conseguindo enfrentar, na rede estudada, o problema da troca de pares informal entre professores, como único meio formativo (insuficiente, sobretudo em territórios vulneráveis), relatado por Breches (2015). E não teria também conseguido interferir nas interações das escolas para que o professor sentisse ter o apoio necessário para enxergar as dificuldades de cada aluno no processo de ensino e aprendizagem, condição para se conseguir a esperada aprendizagem de todos na idade certa.

\section{Descontinuidade dos programas e diretrizes}

O processo de implementação do Pnaic, logo em seu início, entre os anos de 2012 e 2013, na região estudada, enfrentou mudanças e incertezas quando houve a transferência de prefeito da cidade, de Gilberto Kassab (2009-2012) para Fernando Haddad (2013-2016). A gestora Maria (DRE) relata:

RIAEE - Revista Ibero-Americana de Estudos em Educação, Araraquara, v. 16, n. 3, p. 2148-2178, jul./set. 2021. e-ISSN: 1982-5587 
Quando nós assumimos a gestão, já tinha algumas pessoas indicadas para dar a formação para a primeira turma do Pnaic aqui na DRE. É claro que, ao mudar de gestão, muitas pessoas que tinham sido indicadas não quiseram mais [...]. Assim, tivemos que buscar novos formadores. (Gestora Maria).

Percebe-se que, com a mudança de gestão, o programa enfrentou descontinuidade na forma como estava sendo organizado pelo grupo anterior. Maria (DRE) ainda explica que a nova equipe enfrentou dúvidas e incertezas, tendo que lidar com muitas assimilações de um programa em seus primórdios de organização, mas já com algumas diretrizes estabelecidas:

[...] fizeram reuniões com todos os gestores [a SME]. Foi bem no começo da gestão, na reunião de organização. É claro que muitas dúvidas surgiram.... Imagina, as pessoas assumindo uma gestão, explicando uma coisa nova que também estava vindo pra São Paulo e, assim, no começo muitas dúvidas mesmo. (Gestora Maria).

As professoras Mirela (Escola A) e Bruna (Escola A) consideraram a descontinuidade do programa como um ponto negativo do Pnaic:

[...] teria que haver politica de Estado e na verdade acaba não tendo. Porque um governo entra e quer apagar o do anterior. Quando na verdade $o$ que tá sendo bom deveria ser mantido e o que não tá, a gente tentar ajustar pra melhorar. Ainda mais então, essa descontinuidade. Porque no primeiro (primeira formação em 2013) nós tínhamos um cronograma extenso, tinha dois, três encontros mensais, foi bem destrinchado. Com o passar do tempo, parece que ficou só para cumprir... só manteve alguns encontros e foi ficando batido. (Professora Mirela).

Se viesse como no primeiro ano, das formações mais completas, de abranger mais os profissionais, eu acho que teria um trabalho mais direcionado, acho que atingiria mais. E ai o que aconteceu? As formações foram ficando mais escassas. [...] eu acho que um projeto que poderia ter sido bacana, um projeto que poderia ter sido completo, um projeto que poderia ter tido uma influência muito maior, acabou se perdendo. (Professora Bruna).

A professora Bruna (Escola $\mathrm{A}$ ) resume essa questão de descontinuidade não só do Pnaic, mas de uma forma geral nas políticas públicas: “É a nossa política, infelizmente, partidária e não educacional.”

A pesquisa corrobora Torres et al. (2008) no que concerne à afirmação de que a descontinuidade gera instabilidade na escola e implementação incompleta de ações, sem processos de transição, trazendo dificuldades para uma colaboração ou adesão plena. Os dados indicam que se estava frente a agentes de nível meso bastante comprometidos com as ações do Pnaic, entretanto, não puderam fazer face a problemas gerados em instâncias 
hierárquicas superiores e que remetem também aos conflitos próprios das relações entre diferentes entes federados.

Quando inquirida a respeito dos motivos pelos quais houve descontinuidade do Pnaic em 2016 - a formação programada para esse ano só ocorreu no município nos dois últimos meses - a gestora Maria refere que:

[...] foi uma questão mais de contratação mesmo, os acordos governo federal e municipal, não foi uma decisão da Secretaria. Ainda com essas mudanças desse ano que a gente teve, o Pnaic não chegou a ser discutido na esfera federal. Na verdade, quando estava discutindo, teve todo esse processo que a gente tá vivenciando [processo de impeachment contra a Presidente Dilma Roussef]. [...] não sei se algum outro estado conseguiu, ou alguma outra cidade conseguiu... porque dai vai fazendo os contratos, mas pra São Paulo não chegou [a orientação para promover a formação]. (Gestora Maria).

A análise dos dados denota que tais contingências reforçaram a crença, por parte dos entrevistados, de que havia desinteresse dos organizadores em implementar de fato uma política que propiciasse melhoria da qualidade da Educação. Descontinuidade, problemas na distribuição de materiais, execução rápida do que exige mais reflexão, são sinais que parecem remeter a algo que vem de longe, evocando memórias junto aos burocratas de rua, que os fazem simplesmente desacreditar. Como se não valesse à pena investir em mudanças em suas práticas, quando há indicativos de que não é "para valer".

\section{Contexto de vulnerabilidade social e outros fatores sociais que dificultam as condições favoráveis para a aprendizagem}

Ao falarem dos fatores que prejudicam o desenvolvimento de seu trabalho e o desempenho da aprendizagem dos alunos, reiteradamente as professoras se referiram a diversos aspectos relacionados ao não suporte oferecido pelas famílias ao processo escolar, especialmente, quando estão diante de fatores de vulnerabilidade social associados.

[...] você sente que a criança que chega com uma visão de mundo mais ampliada (com acesso a livros), ela chega mais aberta a outras possibilidades, a forma da conversa, o que ela traz, como ela contribui nas atividades que você tá desenvolvendo. E a criança que não tem acesso, e aí é por " $n$ " motivos, como a gente vê, ela fica aquém. (Professora Bruna).

Quanto às expectativas em relação aos alunos vindos de lares com alta vulnerabilidade social, a professora Mirela (Escola A), expressa, nas entrelinhas, a contradição entre se perceber como um profissional que deve ser engajada na evolução da aprendizagem dos 
alunos, - remetendo a Lipsky (2010) com suas observações de que os professores são burocratas de rua engajados - e, ao mesmo tempo, estar em um contexto em que a expectativa sobre esses alunos é baixa.

\begin{abstract}
Enquanto professora, a nossa expectativa é sempre que eles possam evoluir, assim como todo e qualquer cidadão eles possam ter o seu lugar na sociedade e ser bem-sucedido [...]. E a gente se surpreende às vezes, quando a gente vê que o aluno melhorou, que houve mudança e outras infelizmente, que continuam igual ou pior. Então são situações que a gente tem as melhores expectativas, mas para saber vai de caso pra caso, [...]. Não tá assim... nas nossas mãos. (Professora Mirela, grifo nosso).
\end{abstract}

Ao afirmar que "às vezes" esses alunos surpreendem, a professora denota que sua expectativa é que ele efetivamente não aprenda. Razão pela qual encerra seu trecho de fala afirmando que a aprendizagem desses alunos é algo que se reporta a algo fora da relação ensino-aprendizagem, pois está fora de "suas mãos".

A professora Neusa (Escola B) expressa a dificuldade em ser esse professor que precisa ensinar e gerar aprendizagem e, ao mesmo tempo, estar diante de alunos que vivenciam situações sociais que criam limites à sua ação.

[...] eu penso sempre que eu tô dando o melhor de mim e tô fazendo realmente o melhor de mim, se eu tô fazendo isso... o que mais dá pra ser feito? [...] A gente tem que ter o trabalho em conjunto. Quando não dá mais a gente tem que saber, ser humilde o suficiente pra entender que quando não dá pra você sozinha, você tem que pedir ajuda para os parceiros. Sejam os parceiros professores, ou coordenadores, ou gestão. (Professora Neusa).

A coordenadora Laura (Escola B) menciona a vulnerabilidade social no território e sua relação com a alfabetização, afirmando que a situação não pode ser uma desculpa para a não aprendizagem dos alunos, mas relatando as dificuldades do contexto.

Eu entendo que a questão da vulnerabilidade requer ter uma rede de apoio, mas não justifica o menino não aprender, não existe isso. Traz mais desafios. A gente tá hoje num universo que não dá pra dizer que essa escola é redondinha. A gente lida com tudo... a constituição hoje de familia não é mais a mesma, mas ela existe, ela tá aí, e a gente tem que entender que a criança tem que aprender. (Coordenadora Laura).

E cita também o direito à alfabetização e o fato de há professores que não têm clareza sobre esse direito, que independe do contexto:

[...] nosso papel não é resolver a pobreza, nosso papel é fazer com que esse menino tenha o direito dele garantido de aprendizagem. Isso para muitos docentes ainda não tá claro. Isso é uma coisa que não tá claro pra muitos 
docentes, mas é uma luta. Por isso que eu tô nas formações...porque acho que é importante disseminar essa bandeira. (Coordenadora Laura).

Os dados indicam que as professoras não enxergam investimento da política pública para auxiliar alunos em condições de vulnerabilidade. A professora Renata (Escola B) verbaliza esse conflito e localiza um problema que seria externo às suas possibilidades de ação: o desinteresse por parte da própria política em atuar de uma forma a aportar apoio, o que gera sensação de impotência por parte dos professores. Os dados sugerem que o Pnaic, não consolidou, junto aos professores, a visão de que os implementadores da política de nível macro estariam interessados em garantir o direito de aprendizagem das crianças com as quais atuam, objetivo preconizado pelo Programa aqui analisado.

[...] no fundo, a gente quer fazer diferente, a gente quer ajudar, e a minha expectativa é que eles tivessem muita oportunidade. A prefeitura, por exemplo, quanta coisa eu acho que poderia ser feito diferenciado, principalmente com as crianças, porque são muito sozinhos, eles são abandonados. Eles ficam à mercê deles mesmos. Não é só dificuldade na comida, mas eu acho que a maior é a ausência mesmo de familia, a ausência de alguém que cuide. Gostaria que eles (governantes) olhassem para as crianças de forma diferente. Porque a gente consegue ver, porque a gente convive, e muitas vezes você chora e fica triste. É um sentimento terrivel que a gente tem. De se sentir meio que impotente, muitas vezes você não tem muito o que fazer. (Professora Renata, grifo nosso).

A professora Bruna (Escola A) traz uma narrativa que corrobora pesquisas que afirmam ser a escola, muitas vezes, o equipamento público mais forte no contexto de vulnerabilidade social no território de grandes cidades (ERNICA; BATISTA, 2012), enfatizando a importância da escola, do professor e do saber na vida dessas crianças, como meio de ultrapassar o isolamento em termos de informação:

[...] muitas vezes a escola é o único meio, a única oportunidade dela ampliar essa visão mesmo. Porque o mundo dela, familiar, as relações sociais são tão restritas, são tão precárias.... Aí você percebe que se eu não oferecer para o meu aluno algo para que ele possa conhecer que existem outros meios de informação, que existem livros que contribuam para construir o imaginário dele, que existe um outro universo além daquele familiar/social que ele vive, você fica se perguntando se ele vai ter essa oportunidade em outro local e que local é esse? (Professora Bruna).

A professora expõe uma narrativa imersa na contradição entre acreditar que o aluno possa ultrapassar esse isolamento e estar em meio a uma situação social que lhe é bastante adversa, colocando a escola nesse hiato entre estar nesse contexto e ter o potencial de contribuir para o rompimento do ciclo de reprodução da desigualdade. 
Eu acredito sim que ele pode quebrar esse vínculo, esse ciclo. Eu acho que aqui é uma porta para esse novo mundo e para entender que ele tem capacidade de quebrar esse ciclo, mesmo aquele mais vulnerável, eu acredito nisso. É claro que é mais difícil e os desafios são maiores, porque ai você precisa fazer um trabalho de mudança de concepção e de pensamento e de visão da criança para ele atingir o pai também. [...] Então, essa mudança de concepção, de visão é muito dificil, é muito difícil você quebrar isso que está sendo reproduzido, mas eu acredito que o nosso papel aqui é fundamental. Eu acho que é uma sementinha que a gente planta [...]. (Professora Bruna).

Para o gestor Miguel (DRE) a falta de segurança nas escolas é fator fundamental que incide negativamente na implementação de políticas públicas nas regiões de alta vulnerabilidade social: "Eu acho que a gente precisa estudar como que a segurança escolar pode ser resolvida. Tem que aumentar a proteção às escolas. Isso precisa ser resolvido porque o professor quando é atacado, cria um clima ruim." Miguel refere-se também à carência de ofertas culturais na região. Sua consideração a respeito desse assunto envolve o fato de que os próprios educadores estão envoltos nesse ambiente que fica isolado de atividades culturais valorizadas.

[...] eu acho que nossos educadores deveriam ler mais, saber mais, deveriam ter mais acesso à cultura, ao teatro, ao cinema, música... e o pessoal da região precisa ter uma vivência cultural mais permanente, uma cultura diferenciada. Isso ajuda muito o professor. Há muito empenho, muita dedicação, muito compromisso, mas acho que às vezes falta um pouco essa compreensão mais clara e mais profunda de alguns processos culturais. Isso precisa ser superado. (Gestor Miguel).

Esse dado corrobora com a hipótese levantada por Breches (2015), ao estudar escolas dessa região: não são apenas os alunos que estão envoltos no isolamento social relatado pela literatura sobre vulnerabilidade social nos territórios das grandes cidades, os professores também. A ATE Ana (DRE), que foi OE, se reporta à carência de ofertas culturais, entre outras, presentes na região.

Um desafio a ser superado é ter mais áreas de convivência de grupos. Lazer... eu acho que falta muito. O CEU foi um avanço tremendo pra essas regiões. É um local de formação, de lazer, de entretenimento. Mas precisa mais, como a questão de transporte e de segurança... tudo está interligado. (ATE Ana).

Surge também em seu relato o fato da escola servir de apoio logístico em caso de tragédias. "Na última enchente, uma escola teve que abrigar grande parte das pessoas da região". Érnica e Batista (2012) tratam desse aspecto quando falam a respeito da escola e da 
vulnerabilidade social. Os autores afirmam que quando há carência de benefícios sociais no entorno da escola, a instituição é levada a lidar com situações adversas, para as quais não está preparada e que certamente interferem em seu cotidiano, como neste caso aqui relatado por Ana (ATE da DRE).

Observa-se que os relatos aqui presentes confirmam os dados trazidos pela literatura na área de Educação em territórios vulneráveis nas grandes cidades (RIBEIRO; VÓVIO, 2017). A sobreposição de situações que gera desigualdade social nos territórios vulneráveis cria desafios específicos para a escola. A análise dos documentos do Pnaic não denota haver uma diretriz para os agentes implementadores que se encontram em territórios de alta vulnerabilidade social nas grandes cidades. Vargas, Bizelli e Santos Cruz (2020, p. 884), estudando dados e índices calculados pelo Inep, concluem que:

a rede municipal [inclusive em São Paulo] possui mais inputs positivos escolas com níveis de gestão menos complexos, professores mais regulares e menos sobrecarregados, menor média de alunos por sala e carga horária similar ao estado nos anos iniciais do EF - e, no entanto, apresenta resultados inferiores aos obtidos pela rede estadual: maior taxa de distorção idade-série e menor desempenho no IDEB.

Uma das hipóteses explicativas desses autores é que as escolas municipais costumam estar localizadas em regiões periféricas, em localidades que apresentam mais desafios às gestões escolares. Essa hipótese leva a inferir que os estudos sobre vulnerabilidade social no território estão explicitando conhecimento relevante: promover alfabetização (ou qualquer aprendizagem escolar) em meio à condição de sobreposição de desigualdades é um desafio. E, nesta pesquisa, este desafio é explicitamente reconhecido pelos agentes implementadores de nível meso. Não há, entretanto, relatos de adaptações de práticas relativas ao Pnaic devido ao fato de estarem atuando em territórios vulneráveis. Os relatos indicam a existência de uma compreensão, entre implementadores de nível meso, do impacto da vulnerabilidade social do território sobre a escola, como um problema "latente", que não chega a se converter em estratégias de implementação que apoiem os professores que lidam cotidianamente com tais situações. No que concerne ao enfrentamento das sobreposições das desigualdades que afetam os estudantes nesse território, os professores se percebem sozinhos, diante do seu difícil papel de burocrata de rua engajado, conforme aponta Lispky (2010), imerso nas contradições entre representações sociais desfavoráveis aos alunos e seu papel de responsáveis por sua aprendizagem. 


\section{Considerações finais}

Esse artigo teve como objetivo analisar a implementação do Pnaic em uma região de alta vulnerabilidade social do município de São Paulo. Para tanto, foram realizadas entrevistas com 10 profissionais que participaram dessa implementação, além de uma profissional consultora na área de Educação. Procurou-se verificar como ocorreram os processos de implementação de acordo com as seguintes categorias prévias: adesão dos agentes aos processos de implementação; formações e treinamentos propostos; ações discricionárias presentes em suas ações; processos de interação e o contexto institucional; descontinuidade dos programas e diretrizes; além da influência do contexto de vulnerabilidade social.

Conclui-se que, na regional estudada, não foi possível contar com a plena adesão dos professores aos processos de implementação do Pnaic. Embora as formações tenham sido consideradas enriquecedoras por promover, segundo os professores, trocas de experiências e também por elucidar dúvidas, os dados das escolas mostram poucas modificações nas práticas didáticas e de gestão e indicam para hipótese de que o Pnaic pode não ter impactado o ambiente educacional do ponto de vista de constituir interações capazes de gerar um ensino focalizado na aprendizagem de todos na idade certa. Novas pesquisas poderiam focalizar mais detalhadamente esta questão. Os dados indicam também que houve rejeição, desmotivação e desinteresse dos professores pelas propostas, materiais didáticos e cursos de formação do Pnaic, motivados especialmente por fatores como: falhas no planejamento e execução do programa, relacionados à descontinuidade dos cursos; falha no acesso a materiais de apoio; critérios para escolha dos participantes (não adaptados ao contexto do município, excluindo coordenadores e jovens professores); e, sobretudo, entendimento parcial ou desvirtuado da proposta de trabalho (devido a valores e referências anteriores dos agentes, como as atividades com consciência fonológica, confundida com método fônico); além da crença de falta de interesse do governo pelo programa.

A discricionariedade foi utilizada para adequar diretrizes de acordo com o públicoalvo, devido à rejeição a aspectos do programa (como a questão da consciência fonológica). Foi utilizada também para correção do que se considerou uma falha no Programa: a ausência dos coordenadores pedagógicos nas formações, incluídos pelos gestores da DRE em cursos paralelos.

Agentes de nível meso afirmaram compreender a questão da vulnerabilidade como um problema "latente", com sobreposição de desigualdades, entretanto, não se verificou estratégias que apoiassem as escolas e os professores a fim de garantir a alfabetização plena 
nessas condições. Os professores se mostraram imersos na contradição entre estar num ambiente propício à baixa expectativa sobre os alunos e serem agentes implementadores do tipo “engajado", conforme aponta Lipsky (2010), responsáveis pela alfabetização das crianças. As adaptações por eles realizadas, segundo afirmaram, tinham o objetivo de gerar aprendizagem. Porém não fica claro se essas adaptações ocorreram devido à crença na aprendizagem ou devido a valores que indicam que os alunos não seriam capazes de aprender os conteúdos dos materiais. Novas pesquisas poderiam esclarecer essa questão.

Este estudo ratifica ponderações advindas de outras pesquisas realizadas em territórios vulneráveis (RIBEIRO; VOVIO, 2017; TORRES et al., 2008): a fim de ampliar a qualidade na educação nesses territórios e eliminar as desigualdades educacionais, deve-se promover e acompanhar a implementação de políticas públicas integradas, com ações que consideram as especificidades desses contextos; identificar e considerar valores, crenças e referências dos agentes implementadores; planejar objetivos plausíveis e de longo prazo, garantindo sua continuidade e processos de transição. Agrega a tais estudos outros pontos: a necessidade de promover formações contínuas que lidam com os valores dos profissionais e com a cultura institucional que sustenta o modo como os profissionais interagem entre si, uma vez que essa parece ser a chave para o apoio que tais profissionais necessitam para garantir a aprendizagem de todos os alunos. E também a necessidade de se promover treinamentos específicos aos profissionais que lidam com situações de vulnerabilidade e de inclusão a fim de melhor prepará-los para garantir a aprendizagem básica com qualidade e equidade educacional.

AGRADECIMENTOS: Agradecemos à Fundação de Amparo à Pesquisa do Estado de São Paulo (FAPESP), pelo apoio a esta pesquisa. E também aos agentes implementadores da rede municipal de ensino de São Paulo que, comprometidos com suas ações, gentilmente nos concederam entrevistas e compartilharam conosco saberes e percepções.

\section{REFERÊNCIAS}

ALFERES, M. A.; MAINARDES, J. O Pacto Nacional pela Alfabetização na Idade Certa em ação: revisão de literatura. Ensaio: aval. pol. públ. Educ., Rio de Janeiro, v. 27, n. 102, p. 47-68, mar. 2019.

ALVES, L. et al. Seleção velada em escolas públicas: práticas, processos e princípios geradores. Educação e Pesquisa, São Paulo, v. 41, n. 1, p. 137-152, jan. /mar. 2015. 
ARRETCHE, M. Uma contribuição para fazermos avaliações menos ingênuas. In:

MOREIRA, M. C.; CARVAlhO, M. C. B. (org.). Tendências e Perspectivas na Av. de Pol. e Prog. Sociais. São Paulo: IEE/PUCSP, 2001.

BATISTA, A. A. G.; CARVALHO-SILVA, H. Família, escola, território vulnerável. São Paulo: Cenpec, 2013.

BRASIL. Portaria no 897, de 4 de julho de 2012. Institui o Pacto Nacional pela Alfabetização na Idade certa e as ações do Pacto e define suas diretrizes. Brasília, DF, 5 jul. 2012a. Disponível: https://www.in.gov.br/materia//asset_publisher/Kujrw0TZC2Mb/content/id/10857301/do1-2018-04-18-portaria-n-897-de-4de-abril-de-2018-10857297. Acesso em: 10 jan. 2018.

BRASIL. Resolução CD/FNDE no 4, de 16 de novembro de 2012. Altera a Resolução CD/FNDE $n^{\circ}$ 62, de 11 de novembro de 2011. Brasília, DF, 16 nov. 2012b. Disponível: https://www.fnde.gov.br/acesso-a-informacao/institucional/legislacao/item/3514resolu $\% \mathrm{C} 3 \% \mathrm{~A} 7 \% \mathrm{C} 3 \% \mathrm{~A} 30-\mathrm{n} \% \mathrm{C} 2 \% \mathrm{BA}-4-d e-16-d e-m a r \% \mathrm{C} 3 \% \mathrm{~A} 7 \mathrm{o}-\mathrm{de}-2012$. Acesso: em 10 fev. 2018 .

BRASIL. Resolução CD/FNDE no 4, de 27 de fevereiro de 2013. Estabelece orientações e diretrizes para o pagamento de bolsas de estudo e pesquisa para a Formação Continuada de Professores Alfabetizadores, no âmbito do Pacto Nacional pela Alfabetização na Idade Certa. Brasília, DF, 27 fev. 2013. Disponível: http://www.fnde.gov.br/index.php/acesso-ainformacao/institucional/legislacao/item/4306-resolu $\% \mathrm{C} 3 \% \mathrm{~A} 7 \% \mathrm{C} 3 \% \mathrm{~A} 3 \mathrm{o}$-cd-fnden\%C2\%BA-4,-de-27-de-fevereiro-de-2013. Acesso: em 20 ago. 2017.

BRECHES, B. Formação continuada em uma escola de território vulnerável do município de São Paulo. 2015. 117 f. Dissertação (Mestrado) - Universidade Cidade de São Paulo, São Paulo, 2015.

CHRISTOVÃO, A. C.; SANTOS, M. M. S. A escola na Favela ou a Favela na escola? In: RIBEIRO, L. C. Q. et al. (org.). Desigualdades urbanas, desigualdades escolares. Rio de Janeiro: Letra Capital: Obs. das Metrópoles: IPPUR/UFRJ, 2010. p. 277-297.

ÉRNICA, M.; BATISTA, A. A. G. A escola, a metrópole e a vizinhança vulnerável. Cadernos de Pesquisa, v. 42, n. 146, p. 640-666, maio/ago. 2012.

GATTI, B. A.; NUNES, M. M. R. Formação de professores para o ensino fundamental: estudo de currículos das licenciaturas em pedagogia. São Paulo: FCC/DPE, 2009.

HILL, H. C. Understanding Implementation: Street-Level Bureaucrats' Resources for Reform. Journal of Public Administration Research and Theory, v. 13, n. 3, p. 265-282. 2003.

IMBERNÓN, F. Formação docente e profissional: formar-se para a mudança e a incerteza. 7. ed. São Paulo: Cortez, 2009.

INEP. Instituto Nacional de Estudos e Pesquisas Educacionais Anísio Teixeira. Ideb Escola. 2018. Disponível em: http://idebescola.inep.gov.br/ideb/escola/dadosEscola/ 35055759. Acesso em: 10 jan. 2018. 
KAZTMAN, R. Notas sobre la medición de la vulnerabilidad social. 5 taller regional, la medición de la pobreza, métodos e aplicaciones. BID-BIRF-CEPAL, México, 2000. Disponível em: http://www.cepal.org/deype/mecovi/docs/TALLER5/24.pdf. Acesso em: 10 ago. 2016.

KOSLINSKI, M. C.; ALVES, F.; LANGE, W. Desigualdades educacionais em contextos urbanos: um estudo da geografia de oportunidades educacionais na cidade do Rio de Janeiro. Educação \& Sociedade, Campinas, v. 34, n. 125, p. 1175-1202, out./dez. 2013.

LIPSKY, M. Street-level bureaucracy: dilemmas of the individual in public services. Original edition published in 1980. Russell Sage Foundation. New York, 2010.

LOTTA, G. A política pública como ela é: contribuições dos estudos sobre implementação para a análise de políticas públicas. In: LOTTA, G. (org.). Teoria e análises sobre implementação de políticas públicas no Brasil. Brasília: Enap, 2019. p. 11-38.

LOTTA, G. Agentes de implementação: uma forma de análise de políticas públicas. Cadernos Gestão Pública e Cidadania, São Paulo, v. 19, n. 65, jul./dez. 2014.

LOTTA, G. O papel das burocracias do nível da rua na implementação de políticas públicas: entre o controle e a discricionariedade. In: FARIA, C. A (org.). Implementação de políticas públicas: teoria e prática. Belo Horizonte: PUCMINAS, 2012.

LOVATO, R. G. O pacto nacional pela alfabetização na idade certa (PNAIC/2013) e os professores do município de Castelo ES. 2016. 204 f. Dissertação (Mestrado) Universidade Federal de Minas Gerais, Belo Horizonte, 2016.

MANZANO, T. S. Formação continuada de professores alfabetizadores do Pacto Nacional pela Alfabetização na Idade Certa (PNAIC) no Município de São Paulo: proposições e ações. 2015. 127 f. Dissertação (Mestrado) - Pontifícia Universidade Católica de São Paulo, São Paulo, 2015.

MARCUCCI, F. A educação nas grandes metrópoles: ensino de Língua Portuguesa em São Miguel Paulista. 2015. 218 f. Dissertação (Mestrado) - Escola de Filosofia, Letras e Ciências Humanas, Universidade Federal de São Paulo, São Paulo, 2015.

MENEZES, E. T.; SANTOS, T. H. Verbete Profa (Programa de Formação de Professores Alfabetizadores). Dicionário Interativo da Educação Brasileira - Educabrasil. São Paulo: Midiamix, 2001.

OBSERVATÓRIO DO PNE. Programa Ler e Escrever. Observatório do PNE. Disponível em: http://www.observatoriodopne.org.br/metas-pne/5-alfabetizacao/ programasgoverno/programa-ler-e-escrever. Acesso em: 10 ago. 2017.

PEREIRA-SILVA, C. Vulnerabilidade social nos territórios das grandes cidades, educação e o princípio de justiça como equidade na escola. 2016. 97 f. Dissertação (Mestrado em Educação) - Universidade Cidade de São Paulo, São Paulo, 2016.

QEDU. 2018. Disponível em: http://www.qedu.org.br. Acesso em: 10 jan. 2018. 
RIBEIRO, L. C. Q.; KOSLINSKI, M. C. A. Fronteiras Urbanas da Democratização das Oportunidades Educacionais: o caso do RJ. In: RIBEIRO, L. C. Q. et al. (org.).

Desigualdades urbanas, desigualdades escolares. Rio de Janeiro: Letra Capital: Obs. das Metrópoles: IPPUR/UFRJ, 2010. p. 121-154.

RIBEIRO, V. M.; VOVIO, C. L. Desigualdade escolar e vulnerabilidade social no território. Educ. rev., Curitiba, n. spe. 2, p. 71-87, set. 2017.

RIBEIRO, V. Mendes. Que princípio de justiça para a educação básica? Cadernos de Pesquisa, v. 44, n. 154, p. 1094-1109, 2014.

SÃO PAULO (Município). Secretaria Municipal de Educação. Diretoria de Orientação Técnica. Programa Mais Educação São Paulo: subsídios para a implantação/Secretaria Municipal de Educação. São Paulo: SME/DOT, 2014.

SÃO PAULO (Município). Secretaria Municipal de Educação. Diretoria de Orientação Técnica. Programa de Reorganização Curricular e Administrativa, Ampliação e Fortalecimento da Rede Municipal de Ensino de São Paulo: "Mais Educação São Paulo". São Paulo: SME/DOT, 2013.

SEADE. Índice Paulista de Vulnerabilidade Social - IPVS. São Paulo: Fundação Sistema Estadual de Análise de Dados (SEADE), 2010. Disponível em: http://indiceslp.al.sp.gov.br/view/index.php? prodCod=2. Acesso em: 10 jul. 2016.

TARDIF, M. Saberes docentes e formação profissional. Rio de Janeiro: Vozes, 2014.

TORRES, H. G. et al. Educ. na periferia de SP ou como pensar as desigualdades educacionais? In: RIBEIRO, L. C. Q.; KAZTMAN, R. A Cidade contra a Escola? Segregação urbana e desigualdades educacionais em grandes cidades da América. Rio de Janeiro: Letra Capital, 2008. p. 59-90.

TORRES, H. G. et al. Perfis do Professorado da Rede Pública de SP: a Interação entre Espaço, Regras Institucionais e Escolhas Individuais no Resultado de uma Política Pública. Cadernos Cenpec, São Paulo, v. 3, n. 1, p. 125-158, jun. 2010.

VARGAS, T. C.; BIZELLI, J. L.; SANTOS CRUZ, J. A. Política de municipalização: avaliação do desempenho escolar. Revista Brasileira de Política e Administração da Educação - Periódico científico editado pela ANPAE, v. 36, n. 3, p. 869-888, nov. 2020. ISSN 2447-4193. DOI: https://doi.org/10.21573/vol36n32020.104814

XAVIER, R. S. S. F.; BARTHOLO, T. L. Os impactos do pacto nacional pela alfabetização na idade certa: uma revisão sistemática. Educ. rev., Belo Horizonte, v. 35, e211143. 2019. 


\section{Como referenciar este artigo}

DI GIUSTO, S. M. N.; RIBEIRO, V. M.; VÓVIO, C. L. A implementação do Pnaic em território vulnerável no município de São Paulo. Revista Ibero-Americana de Estudos em Educação, Araraquara, v. 16, n. 3, p. 2148-2178, jul./set. 2021. e-ISSN: 1982-5587. DOI: https://doi.org/10.21723/riaee.v16i3.15413

Submetido em: 10/12/2020

Revisões requeridas em: 05/01/2021

Aprovado em: 10/02/2021

Publicado em: 01/07/2021 